\title{
"Determining and predicting correlation of macroeconomic indicators on credit risk caused by overdue credit"
}

\begin{tabular}{|c|c|}
\hline \multirow{3}{*}{ AUTHORS } & Asie Tsintsadze (D) https://orcid.org/0000-0002-4493-8872 \\
\hline & Lela Oniani (D https://orcid.org/0000-0002-5960-4015 \\
\hline & Tamar Ghoghoberidze (D https://orcid.org/0000-0001-6701-5029 \\
\hline ARTICLE INFO & $\begin{array}{l}\text { Asie Tsintsadze, Lela Oniani and Tamar Ghoghoberidze (2018). Determining } \\
\text { and predicting correlation of macroeconomic indicators on credit risk caused by } \\
\text { overdue credit. Banks and Bank Systems, 13(3), 114-119. } \\
\text { doi:10.21511/bbs.13(3).2018.11 }\end{array}$ \\
\hline DOI & http://dx.doi.org/10.21511/bbs.13(3).2018.11 \\
\hline RELEASED ON & Wednesday, 19 September 2018 \\
\hline RECEIVED ON & Friday, 06 July 2018 \\
\hline \multirow[t]{2}{*}{ ACCEPTED ON } & Friday, 31 August 2018 \\
\hline & $((c)$ EY \\
\hline LICENSE & $\begin{array}{l}\text { This work is licensed under a Creative Commons Attribution } 4.0 \text { International } \\
\text { License }\end{array}$ \\
\hline JOURNAL & "Banks and Bank Systems" \\
\hline ISSN PRINT & $1816-7403$ \\
\hline ISSN ONLINE & $1991-7074$ \\
\hline PUBLISHER & LLC "Consulting Publishing Company "Business Perspectives" \\
\hline FOUNDER & LLC "Consulting Publishing Company "Business Perspectives" \\
\hline
\end{tabular}

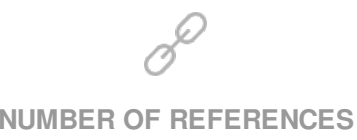

13
NUMBER OF FIGURES

4
NUMBER OF TABLES

1

(C) The author(s) 2023. This publication is an open access article. 


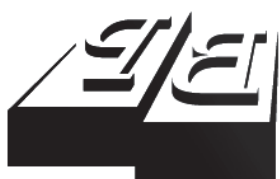

BUSINESS PERSPECTIVES

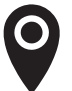

LLC "CPC "Business Perspectives" Hryhorii Skovoroda lane, 10, Sumy, 40022, Ukraine

www.businessperspectives.org

Received on: $6^{\text {th }}$ of July, 2018 Accepted on: $31^{\text {st }}$ of August, 2018

(C) Asie Tsintsadze, Lela Oniani, Tamar Ghoghoberidze, 2018

Asie Tsintsadze, Professor, Batumi Shota Rustaveli State University, Georgia.

Lela Oniani, Associate Professor, Batumi Shota Rustaveli State University, Georgia.

Tamar Ghoghoberidze, Ph.D. student, Batumi Shota Rustaveli State University, Georgia.

\section{(c) (i)}

This is an Open Access article, distributed under the terms of the Creative Commons Attribution 4.0 International license, which permits unrestricted re-use, distribution, and reproduction in any medium, provided the original work is properly cited.
Asie Tsintsadze (Georgia), Lela Oniani (Georgia),

Tamar Ghoghoberidze (Georgia)

\section{DETERMINING AND PREDICTING CORRELATION OF MACROECONOMIC INDICATORS ON CREDIT RISK CAUSED BY OVERDUE CREDIT}

\begin{abstract}
The banking system guarantees the economic strength of the country. Its sustainability is due to the sustainability of the credit portfolio. Therefore, scientific research on banking risks is always relevant. Basel recommendations and central bank regulations provide risk minimization in case of default of borrower by creating risk reserve, but the high range of macroeconomic factors creates a basis for creating credit risk. The model, which determines the risk factors, may be structurally the same, but the quality of the influence of factors is different in various countries. The influence of macroeconomic factors is particularly evident in developing countries. The impact of economic factors in different countries is high in GDP of these countries. The article focuses on determining the influence of macroeconomic factors on credit risk of systematic banks in Georgia. The coefficients of individual macroeconomic indicators are calculated by using Pearson's correlation. The credit risk ratio is taken from the bank's overdue credits and credit portfolio ratio. Based on the correlation coefficients obtained, the expected risk of shock changes is calculated.
\end{abstract}

\section{Keywords}

JEL Classification risk, Pearson's correlation, macroeconomic indicators, shock changes

G21, G38

\section{INTRODUCTION}

Credit risk is a major threat to banking activities that cannot be completely eliminated. Like the production cycle, Credit risk management is a difficult and lengthy process and it includes full coverage of the credit amount and interest income accrued from the client's application. A variety of approaches to the improvement of credit risk management models and mechanisms in scientific circles are examined. For many years, financial institutions were facing financial stability problems. Among the reasons, the first was the credit risk, which scientists think was caused by weak credit standards and low quality of their protection. The borrower has been receiving credit in accordance with the financial condition of the loan in the process of taking the loan, but the borrower's condition deteriorated due to changes in the borrower's business, economic policies and other changes, resulted in a credit risk. There is no separate credit risk measurement tool, as credit risk is not caused itself, but by the influence of operational and market risks.

\section{LITERATURE REVIEW}

Aver (2008), in his work "An Empirical Analysis of Credit Risk Factors of Slovenian Banking System", investigates the influence of macro- 
economic factors on credit risk. Factors operating on credit risk are united into two factors, the first factor is the interest rate, and the second factor includes all other macroeconomic factors. Based on the analysis obtained during the research, the importance of the first factor is high and the influence of other macroeconomic factors in the other factor is secondary, then the banking system's credit risk is higher than average. On the other hand, the low impact of both factors shows that the risk in credit portfolio is lower than average (Aver, 2008). The established ratio is a significant indicator of credit risk research, but findings can be changed as a result of the current situation changes in the country.

Musau et al. (2017), in the work "Financial Inclusion, GDP and Credit Risk of Commercial Banks in Kenya", discuss credit risk as a combination of the total loans for overdue loans and evaluate three factors: access to bank resources, availability of credits and the level of use. Based on the theoretical analysis and the financial intermediaries, the conclusion is that the credit risk affects the quality of financial engagement and partial GDP. The Kenyan banking sector's 2007-2005 regressive analysis confirms that access to banking resources reduces credit risk and stabilizes the banking system and the level of accessing to consumer credits increases credit risk and threatens the stability of the banking sector. Bank deposit is an important part of money supplied by the bank. The growth of deposits is directly related to GDP growth. The outcome of the author will be changed for the banking system with other data because the level of financial engagement is the growth rate of GDP in the country. GDP growth is correlated with the level of employment.

\section{METHODS}

Jakubik, in the work "Macroeconomic Credit Risk Model", has proposed a credit risk assessment model that defines the share of outstanding loans in the credit portfolio. The approach of the author allows the influence of macroeconomic shocks to predict the influence of macroeconomic variables in the long run. The model is based on the normal distribution law and the accuracy is high when the variables in the risk of change are within the norm. Basel's recommendations and regulations of central banks ensure the risk of minimization in case of defaults of borrowers, but with the high range of macroeconomic factors lead to a credit risk formation. The model, which determines the risk factors, may be structurally the same, but the quality of the influence of factors is different in different countries. The influence of macroeconomic factors is particularly evident in developing countries. The article focuses on determining the impact of macroeconomic factors on the credit risk of Georgia's System Bank. By using Pearson's correlation to increase accuracy, the coefficients of individual macroeconomic indicators are calculated. The credit risk ratio is taken from the bank's overdue credits and credit portfolio ratio.

\section{RESULTS}

The study of financial data of the Bank found that $79-98 \%$ (2011-2017) of the bank's credit portfolio was credited to individuals.

The financial crisis caused by the unbalanced economic situation of the country (2008-2009) has caused military conflict to reduce the solvency of individuals, reflecting the loss of jobs. The work deals with a correlation of credit risk due to overdue credits, based on the system "Bank of Georgia", with the macroeconomic factors and the coefficient obtained by the quality of influence as a result of growth factors in future credit risk.

Pearson's correlation coefficient is used to determine the risk of credit risk for macroeconomic indicators. Pearson's coefficient describes the linear dependence between the variables, but in this case, it does not have a strictly linear dependency, but the advantage of the use of Pearson's correlation can be explained by the fact that the impact of the individual factor on credit risk can be determined. At the same time, it should be noted that the unemployment rate has not been realized and inflation is rising due to emerging factors outside the country, and their regressive multi-factor model could not be realized. The use of Pearson's correlation method requires the following conditions: linear correlation between variables, the subordination of the normal distribution of economic processes. 
Table 1. The result of the calculation of Pearson's correlation

Source: Authors' calculation.

\begin{tabular}{|c|c|c|c|c|c|c|c|c|c|c|}
\hline \multirow{2}{*}{$\begin{array}{c}\text { The bank } \\
\text { X }\end{array}$} & \multirow{2}{*}{$\begin{array}{c}\text { Y-overdue } \\
\text { credits/credits } \\
\text { issued, percent }\end{array}$} & \multirow{2}{*}{$\begin{array}{c}X_{1-} \\
\text { unemployment } \\
\text { rate, percent }\end{array}$} & \multirow{2}{*}{$\begin{array}{c}X_{2}-\text { GDP } \\
\text { growth rate, } \\
\text { percent }\end{array}$} & \multirow{2}{*}{$\begin{array}{l}X_{3} \text {-inflation } \\
\text { rate, percent }\end{array}$} & \multicolumn{3}{|c|}{$\begin{array}{c}\text { Pearson's correlation } \\
\text { coefficient }\end{array}$} & \multicolumn{3}{|c|}{$\begin{array}{c}\text { Pearson's correlation } \\
\text { criterion }\end{array}$} \\
\hline & & & & & $\mathbf{R}_{x 1 y}$ & $\mathbf{R}_{\mathrm{x} 2 \mathrm{y}}$ & $\mathbf{R}_{x 3 y}$ & $\mathrm{tr}_{1}$ & $\mathbf{t r}_{2}$ & $\mathbf{t r}_{3}$ \\
\hline 2007 & 22.0 & 17.4 & 12.3 & 11.0 & \multirow{11}{*}{0.43} & \multirow{11}{*}{0.62} & \multirow{11}{*}{0.08} & \multirow{11}{*}{0.9} & \multirow{11}{*}{0.89} & \multirow{11}{*}{0.24} \\
\hline 2008 & 5.0 & 17.9 & 2.6 & 5.5 & & & & & & \\
\hline 2009 & 24.0 & 18.3 & 3.7 & 3.0 & & & & & & \\
\hline 2010 & 12.0 & 17.4 & 6.2 & 11.2 & & & & & & \\
\hline 2011 & 11.0 & 17.3 & 7.2 & 2.0 & & & & & & \\
\hline 2012 & 7.0 & 17.2 & 6.4 & -2.4 & & & & & & \\
\hline 2013 & 6.0 & 16.9 & 3.4 & 2.4 & & & & & & \\
\hline 2014 & 12.0 & 14.6 & 4.6 & 2.0 & & & & & & \\
\hline 2015 & 9.0 & 14.1 & 2.9 & 4.9 & & & & & & \\
\hline 2016 & 11.0 & 14.0 & 2.8 & 1.8 & & & & & & \\
\hline 2017 & 1.0 & 13.9 & 5.0 & 6.7 & & & & & & \\
\hline
\end{tabular}

The authors guarantee that the change in the parameters is subject to the normal distribution law. The schedule of individual macroeconomic indicators and credit risk connection (see Figure 1 in the Appendix) is designed to determine linear dependence.

The results of Pearson's correlation coefficient, the criterion of critical criteria are reflected in Table 1.

$\mathrm{R}_{\mathrm{xly}}=0.43$ (unemployment) - under the interval of the value of Pearson's correlation coefficient, the correlation between the credit risk and the unemployment rate in the country during 2007-2017 is lower than average (see Figure 2 in the Appendix). The criterion of the personnel is determined to indentified the correlation between the importance of the correlation and was compared to the critical criterion (see Table 1). $t r_{1}=0.9, t r_{\text {Critical }}=0.60$, when $p \leq$ 0.05 and $t r_{\text {Critical }}=0.74$, when $p \leq 0.01$, i.e. $t r_{1}=$ $0.9>t_{\text {Critical }}$. As one can see, in spite of low correlation, unemployment is statistically significant for the credit risk assessment caused by overdue.

$R_{x 2 y}=0.62$ (GDP ratio $t r_{\text {Critical }}=0.60$, when $p \leq$ 0.05 and $t r_{\text {Critic }}=0.74$, when $p \leq 0.01$. Critical criterion terms, $t r_{2}>t_{\text {Criticism }}$, which implies that correlation is correct. In both cases, $95-99 \%$ reliability is correlation with the tempo) is higher than average. Correlation criterion $t r=0.89$, in this case $t_{\text {Critical }}=0.60$, when $p \leq 0.05$ and $t_{\text {Critic }}=$ 0.74 , when $p \leq 0.01$. Thus, $t r>t_{\text {Critical }}$ and credit risk. The GDP's influence level is true with 95-99\%.

$R_{x 3 y}=0.08$ (correlation with inflation rate) is weak. Correlation criteria $\operatorname{tr}_{3}=0,24, t_{\text {Critical }}=$ 0.60 , and $t_{\text {Critical }}=0.74$. The values confirm that the connection between inflation and credit risks is not accidental, but the weakest correlation of the most sensitive macroeconomic indicators is the question of how inflation is at risk of inflation weakening influence.

According to the authors, the National Bank of Georgia instantly launches its monetary leverage and changes the short-term interest rate for the price stability, which will be reflected in the economy through the transfer mechanism, in particular through the credit transfer channel credit card.

The increased rate of policy will be transferred to the money market, which will be reflected on a short-term interest rate, and then affects the long-term interest rate. In these conditions, credit availability is difficult, low credit plans are reduced, companies are trying to get higher revenues in high-risk investment projects, increased interest rates raise the credit service coefficient, thus the bank tightens the terms of the loan is- 
suance and reduces the lending of the economy, which also leads to mitigating credit risk.

Although the formation of monetary policy is based on the target inflation rate, Georgia has the small and open economy and has no less impact on the shaky processes developed in partner countries, as a result of inflation forecasted by target inflation.

The correlation coefficients are calculated according to the credit risk of most of the impact of the gross domestic product of the unemployment rate and the inflation rate, but in Table 1, the annual data comparison shows that the higher credit risk corresponds to the case of the gross domestic product at a high rate, in other cases, the lowest indicators I.

Delayed loans in the banking system by December 2016 are $36.6 \mathrm{mln}$. Increased by GEL Of these, $41.5 \%$ are denominated in the national currency, indicating a high level of dollarization. The growth rate of inflation is the lowest (1.8\%) in 2016 from 2007-2017. It is also evident that periodically the impact of inflation is weak on credit risk and credit risk rises because overdue loans are caused by other factors, in particular, increased unemployment, exchange rate, poverty level, inequality of incomes, wrong assessment of risks and more. As for the calculated correlation index (0.08), this is explained by the fact that the monetary policy of the National Bank of Georgia was planned based on the wrong forecasted indicator and, on the other hand, it became a shocking process.

The values of correlation can raise the equation of the linear function between variables, which will be able to determine the impact of the shock processes based on the research rate.

$$
Y=\beta_{0}+\beta_{1} \cdot X_{1},
$$

where $Y$ - the credit risk created by the overdue loan; $X$ - macroeconomic indicator; $\beta_{1}$ - Pearson's correlation coefficient.

$$
\beta_{0}=Y-\beta_{1} \cdot X_{1}
$$

By solving this equation, it is possible to determine the impacts of shock indicators of macroeconomic factors on the rate of research.
Unemployment,

$$
\beta_{0}=10.91-0.43 \cdot 16.27=3.91 \text {. }
$$

Gross Domestic Product,

$$
\begin{aligned}
& \beta_{0}=Y-\beta_{1} \cdot X_{1}= \\
& =10.91-0.62 \cdot 5.19=7.67 .
\end{aligned}
$$

Inflation, $\beta_{0}=10.91-0.08 \cdot 4.37=10.56$.

Assuming that GDP reduction is expected to be $7 \%$, the correlation between the correlation and the reliability of the credibility will be the credit risks caused by overdue loans:

$$
\begin{aligned}
& Y=\beta_{0}+\beta_{1} \cdot X_{1}= \\
& =7.7+0,62 \cdot(-7.0)=3.33 .
\end{aligned}
$$

Thus, credit risk will be reduced by $3.33 \%$. Is this a given situation for a commercial bank and what factors cause credit risk reduction? The GDP cut in itself means a weakening of economic activity, so the bank cannot afford credit and the risk of credit risk reduction (see Figure 3 in the Appendix).

Inflation increases despite the weak correlation, the cause of which is explained above, the credit risk should be high. Suppose that the stress-test scenario was designed to increase the risk of rising inflation by $15 \%$.

$$
\begin{aligned}
& Y=\beta_{0}+\beta_{1} \cdot X_{2}= \\
& =10.56+0.08 \cdot 15.0=9.36 .
\end{aligned}
$$

As one can see, inflation grows by $15 \%$, it is expected to increase credit risk by $9.36 \%$. The actions aimed at the shocks are "stirring" to the National Bank of Georgia and individual commercial banks and enable them to react to the expected events.

As the calculations show, there is an average correlation between the levels of unemployment:

$$
\begin{aligned}
& Y=\beta_{0}+\beta_{1} \cdot X_{2}= \\
& =3.91+0.43 \cdot 8.0=3.94 .
\end{aligned}
$$

In the case of unemployment increase by $8 \%$, credit risk will increase by about $3.94 \%$. This is also natural, because the unemployment rate reduces the income of the population and therefore the bankruptcy of the loans. Correlation with unemployment is not a valid indicator (see Figure 4 in the Appendix). 


\section{CONCLUSION}

The unemployment rate in Georgia has been reduced by the number of employed people, most of which have low income or only for family storage. In recent years, liberalization of credit issuance procedures has played a major role in the growth of overdue loans, especially in commercial banks whose credit portfolio was mainly created by loans from individuals. The authors calculations show the research problems in banking risk management methods, which will enable commercial banks to use the methodology to analyze the risks, identified by the expert assessment by quantitative methods and develop effective measures. Calculations carried out based on the statistical information studied provide the following suggestions:

1. Banks should tighten credit policies and increase customer business risk assessment by shock scenarios in order to minimize credit risk, which will reduce sectoral risks in credit risks.

2. To improve the correlation of credibility, calculations should be based on real data, within the scope of quantitative research to study the impact of the most sensitive factor in the risk-generating factor.

3. It is necessary to estimate the connection between macroeconomic indicators and credit risk caused by overdue loans to determine the quality of credit risks and elaboration of preventive measures during shock change.

\section{REFERENCES}

1. Aver, B. (2008). An Empirical Analysis of Credit Risk Factors of the Slovenian Banking System. Managing Global Transitions, 6(3), 317-334. Retrieved from http:// www.fm-kp.si/zalozba/ISSN/15816311/6_317-334.pdf

2. Belas, J., \& Cipovova, E. (2011). Internal Model of Commercial Bank as an Instrument for Measuring Credit Risk of the Borrower in Relation to Financial Performance (Credit Score and Bankruptcy Models). Journal of Competitiveness, 3(4), 104-120. Retrieved from http://www.cjournal.cz/files/79.pdf

3. Butaru, F., Chen, Q., Clark, B., Das, S., Lo, A. W., \& Siddique, A. (2016). Risk and risk management in the credit card industry. Journal of Banking and Finance, 7(2), 218-239. https://doi.org/10.1016/j. jbankfin.2016.07.015

4. Chornous, G., \& Ursulenko, G. (2013). Risk management in banks: new approaches. Ekonomika, 92(1), 120-132. Retrieved from www.zurnalai. vu.lt/ekonomika/article/download/1131/599
5. Dimitriu, M., Oprea, I. A., \& Scrieciu, M. A. (2012). Credit Risk Modeling using Multiple Regressions. International Journal of Advances in Management and Economics, 1(5), 125-131. Retrieved from http://www.managementjournal.info/index.php/ IJAME/pages/view/indexing

6. Economic Policy Research Center (2014). Management of Non-Performing Loans in Georgia Analysis and Recommendations. Retrieved from https://www.eprc. ge/admin/editor/uploads/files/ Sesxebi_Eng_WEB.pdf

7. Jakubik, P. (2007).

Macroeconomic Environment and Credit Risk. Czech Journal of Economics and Finance, 57(1-2), 60-78. Retrieved from https:// ideas.repec.org/a/fau/fauart/ v57y2007i1-2p60-78.html

8. Musau, S., Muathe, S., \& Mwangi, L. (2018). Financial Inclusion, GDP and Credit Risk of Commercial Banks in Kenya. International Journal of Economics and Finance, 10(3), 181-195. https://doi.org/10.5539/ijef. v10n3p181
9. National Bank of Georgia (2007-2017). Annual Reports of the National Bank of Georgia. Retrieved from https://www.nbg. gov.ge/index.php? $\mathrm{m}=348$

10. National Bank of Georgia (2014). Regulation on Risk Management in Commercial Banks. Retrieved from https://www.nbg.gov.ge/uploads/legalacts/fts/eng/regulation_on_risk_ management_08_07_14.pdf

11. Nunes, T., \& Rodrigues, P. (2010). Threshold effects in credit risk and stress scenarios. International Journal of Economics and Finance, 16(4), 393-407. https://doi. org/10.1002/ijfe.436

12. Oniani, L., \& Ghoghoberidze, T. (Eds.) (2017). Modern method of banking risk assessment. Proceedings from Second international conference Economic Development of Economic, Legal and Social Problems of Modern Development, Kutaisi, GE.

13. Tong, X., Feng, Y., \& Li, J. (2018). Neyman-Pearson classification algorithms and NP receiver operating characteristics. Science Advances, 4(2), 1-10. http://dx.doi. org/10.1126/sciadv.aao1659 


\section{APPENDIX}

Source: Consolidated Financial Statements of JSC Bank of Georgia, National Statistics Office of Georgia.

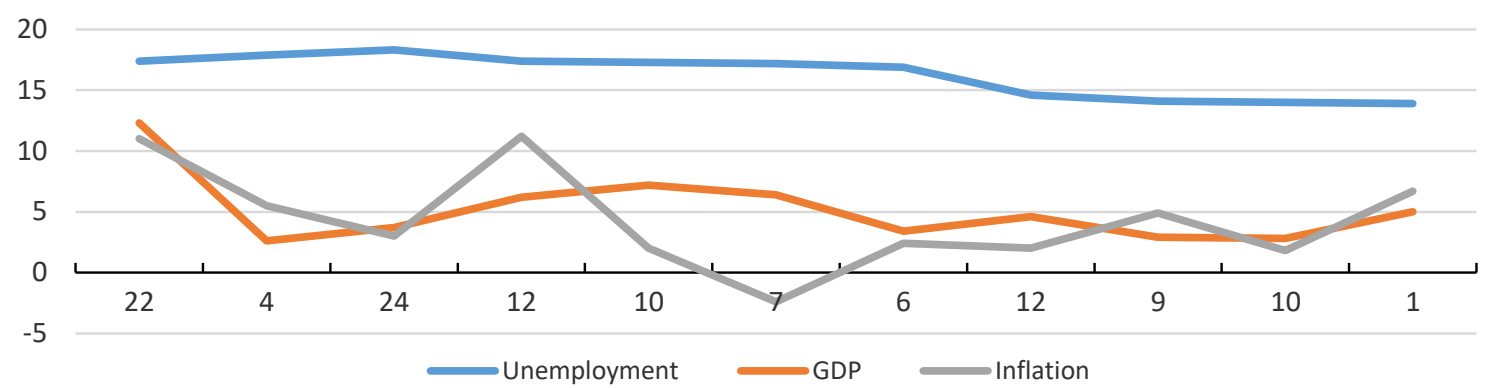

Figure 1. Credit risk of the Bank of Georgia (overdue credit 90+)

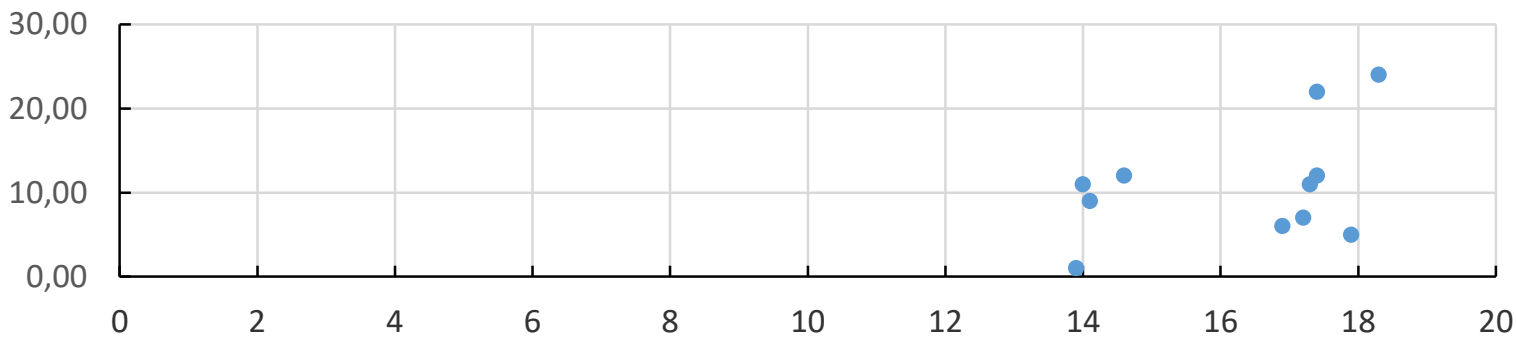

Figure 2. $\mathrm{Y}$-Credit risk, $\mathrm{X}$ - Unemployment rate

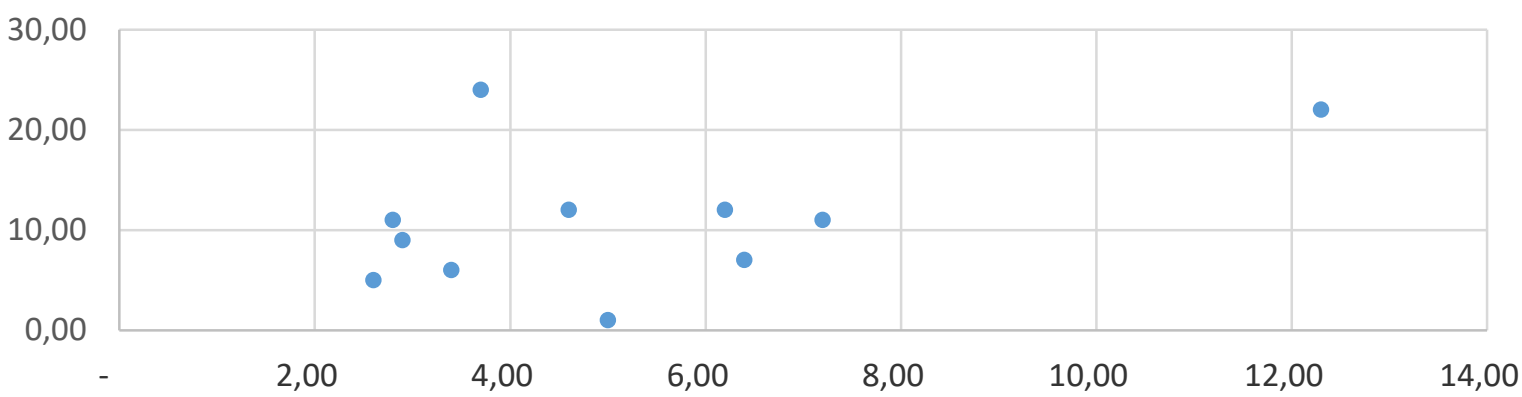

Figure 3. $Y$ - Credit risk, $X-G D P$

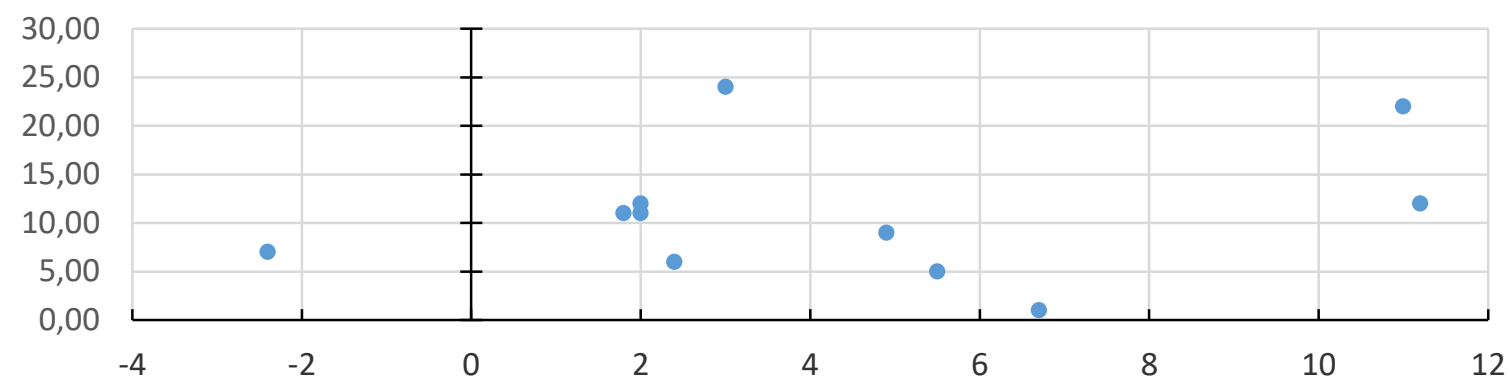

Figure 4. $Y$ - Credit risk 